\title{
ダクロン人工䩲帯による前十字䩲帯再建術の小経験
}

\author{
熊本大学整形外科 \\ 佐久間 克 彦・水 田 博 志 \\ 久保田 健 治・甲 斐 功 一 \\ 高木 克 公
}

\section{Clinical Experience and Short-Term Results of Reconstruction of The Anterior Cruciate Ligament with a Dacron Ligament Prosthesis by}

\author{
Katsuhiko Sakuma, Hiroshi Mizuta, Kenji Kubota, \\ Koichi Kai and Katsumasa Takagi \\ Department of Orthopaedic Surgery, \\ Kumamoto University Medical School, Kumamoto, Japan
}

\begin{abstract}
We studied the short-term results of the anterior cruciate ligament with a Dacron Ligament prosthesis in 7 cases. Our series consisted of three males and four females ranging in age from 17 to 40 years old with an average of 32.3 years old. Follow-up ranged from 3.5 to 12.5 months (average, 9 months). All had chronic anterior cruciate ligament deficient knees. The reconstruction led to complete improvement of giving way phenomenon. Although subjectively all of the patients considered the results satisfactory, objectively we recognized a case of a rupture of intra-articular ligaments and a case whose laxity was gradually increasing. From this study, the short-term results of the anterior cruciate ligament with a Dacron ligament prosthesis did not give us enough satisfaction.
\end{abstract}

\section{はじめに}

前十字勒带機能不全膝に対する外科的治療として, われわれは腸脛靯带を用いた関節鏡視下二重支持再建 術を行っているが, 約 1 年の後療法を要するため, 時 間的に本法を行うことが困難な症例もある。われわれ はそのような症例に対しダクロン人工勒帯を用いた再 建術を行ったので, その短期成績について報告する。

\section{症}

例

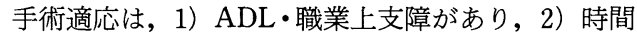
的制約のため長期の後療法が行えないものとしたが, 激しいスポーツ活動への復帰を望むものは除いた。

症例は男 3 例, 女 4 例, 右膝 1 例, 左膝 6 例で, 全 例陳旧例である. 手術時年令は 17 才より 40 才, 平均 37.3 才で経過観察期間は 3.5 力月より 12.5 力月, 平均
9 カ月である.

\section{手 術 術 式}

手術術式は Gillquist の術式に従い，全例に notchplasty を行った。

関節内のみの再建術を行ったものが 4 例，関節外の 再建術を加えたものが 3 例であった。

合併手術として半月部分切除術 4 例, 半月縫合術 1 例を行った。

リハビリテーションのプログラムは表 1 に示すとお りである. 術後 2 週でROM を free とし全負荷歩行と した。術後約 6 週にて退院を許可した。

\section{結果}

術後全例にみられた膝くずれは，術後調查時までの 時点では 1 例もみられていない。 
表 1 リハビリテーションのプログラム

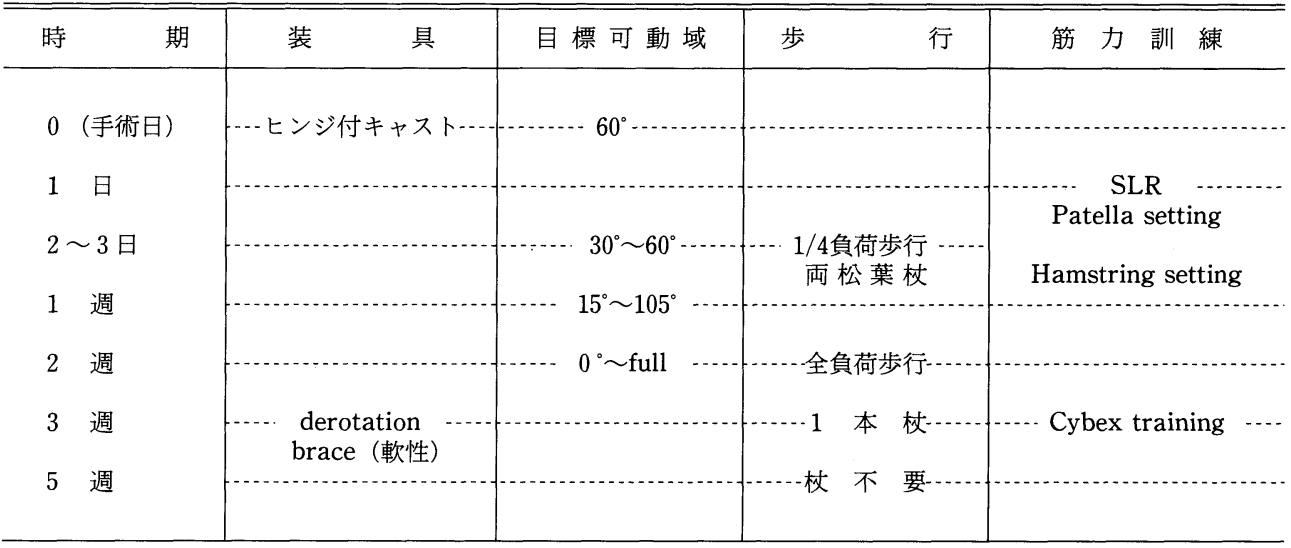

表 2 調査時の $\mathrm{ADL}$ 評価

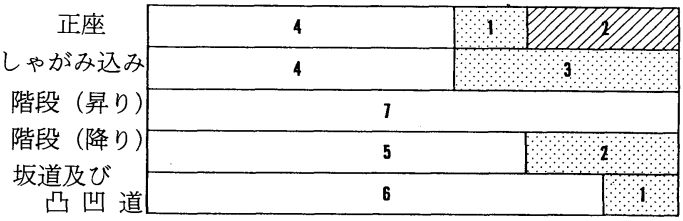

不自由なし やや不自由 西不自由または困難

表 3 術前および検查時の大腿周径差

\begin{tabular}{l|rl|rl}
\hline \hline & 術 & 前 & 調 查 時 \\
\hline $1.0 \sim 2.0(\mathrm{~cm})$ & 2 & 例 & 4 & 例 \\
\hline $2.0 \sim 3.0(\mathrm{~cm})$ & 2 & 例 & 2 & 例 \\
\hline $3.0(\mathrm{~cm})$ 以上 & 3 & 例 & 1 & 例 \\
\hline
\end{tabular}

調査時の $\mathrm{ADL}$ 評価を表 2 に示す.正座は 2 例が行っ ておらず，1例がやや不自由であった。またしゃがみ 込みで 3 例, 階段の降りで 2 例, 坂道や凸凹道歩行で 1 例がやや不自由と答えた。

大腿周径差は, 術後も全例 $1.0 \mathrm{~cm}$ 以上認めるが大半 は術前に比べ改善していた(表 3 )。可動域は調查時全 例制限を認めなかった。

$90^{\circ}$ 屈曲位前方引き出しテスト, Lachman テスト, $\mathrm{N}$ テストの結果を表 4 に示す。術前いずれも全例陽性 であったが, 調査時は前方引き出しテスト $(+) 1$ 例, Lachman テスト $(+) 1$ 例，（土）1例， Nテスト (+) 1 例，（土） 2 例であった。ただし術後約 6 週の退院時 はいずれも全例陰性であった。
単純X線では図 1 に示すように, 症例 1 で関節内で の䩲帯内フィラメントの断裂, 症例 2 でステープルの ルースニング，症例 6 で大腿骨骨孔関節外出口での鞀 帯内フィラメントの断裂を認めた.

$10 \mathrm{~kg}$ 負荷前方ストレス撮影を行った 5 例で患側膝の 術前, 調査時, さらに健側膝の前方移動率を中点計測 法を用いて比較した（図 2 ）。調査時 $70 \%$ 以上の移動 率を示したのは症例 1 および症例 6 の 2 例であった. 症例 1 では調査時の移動率は術前と変化なく, 健側と 比べて大きな移動率を示した。一方症例 6 では調査時 の移動率は 78.1 \%であるが健側膝も $78.0 \%$ \%あった。 症例 1 では術後 11 カ月で関節鏡検査を行った。関節 内の靱帯中央よりやや遠位部で断裂を認め，この部位 は伸展位近くで notchに相当した（図 3 ）。

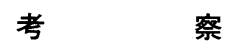

近年人工勒帯は前十字勒帯再建術に対し多く使用さ れる傾向にある，後療法が短い，自家組織を犠牲にし ない点などは，自家組織を用いた術式に比べ大きな利 点である、しかしながらその成績は必ずしも明らかで はない. 今回のわれわれの結果は, 7 例中 1 例に勒帯 の断裂を認め,さらに一部の症例では経時的に動摇性 が増大する傾向にあり, 短期成績として満足できるも のとは言えない．術後成績に影響を及ぼすものとして は, 人工靯帯の特性, 手術術式, 術後のリバビリテー ション, 術後の活動性, 術後経過観察期間など種々の 要素が考えられるが, その中でも大きな影響をもつと 考えられる関節内の骨孔の位置について検討してみた。

計測法は, 側面X線像を用い図 4 のごとく村瀬ら ${ }^{2)}$ の 
表 4 術前扔よび調査時の不安定性

\begin{tabular}{|c|c|c|c|c|c|c|c|c|c|c|c|c|c|c|}
\hline \multirow{2}{*}{ 症 例 } & \multicolumn{4}{|c|}{ 前方引き出しテスト } & \multicolumn{2}{|c|}{ Lachman $\bar{~}$} & ス & \multicolumn{2}{|c|}{ 卜 } & \multicolumn{2}{|c|}{$\mathrm{N}$} & x & \multicolumn{2}{|c|}{ r } \\
\hline & 術 & 前 & & 查 時 & 術 & 前 & 調 & 查 & 時 & 術 & 前 & 調 & 查 & 時 \\
\hline $\begin{array}{l}1 . \\
2 . \\
3 . \\
4 . \\
5 . \\
6 . \\
7 .\end{array}$ & & & & $\begin{array}{l}(+) \\
(-) \\
(-) \\
(-) \\
(-) \\
(-) \\
(-)\end{array}$ & & & & $\begin{array}{l}(+) \\
(-) \\
(-) \\
(-) \\
(-) \\
(-) \\
( \pm)\end{array}$ & 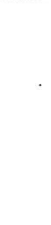 & & & & $\begin{array}{l}(+) \\
( \pm) \\
(-) \\
(-) \\
(-) \\
(-) \\
( \pm)\end{array}$ & \\
\hline
\end{tabular}

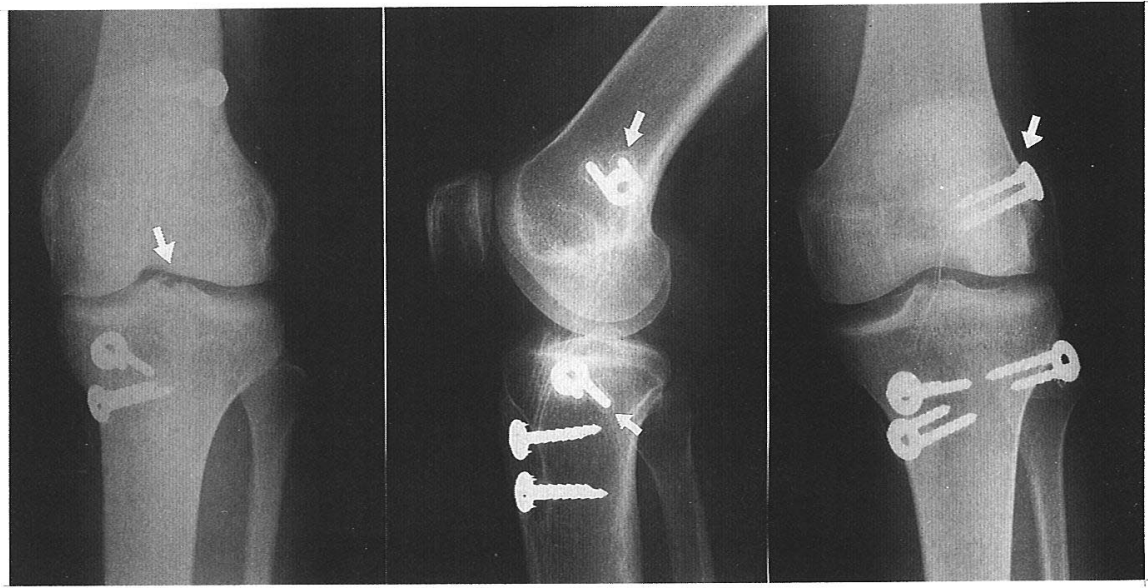

症例 1

症例 2

症例 6

図 1 X線上異常の認められた症例

症例 $1:$ 関節内靱帯内フィラメントの断裂

症例 2 : ステープルのゆるみ

症例 3 : 大腿骨骨孔関節外出口での靱帯内フィラメントの断裂

方法にしたがい関節内の脛骨・大腿骨の骨孔の位置を 計測した。

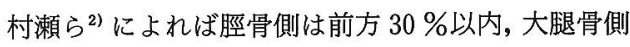
は前後方向で $60 \%$ 以上，上下方向で $50 \%$ 以上の領域 を至適領域とし，この領域に骨孔が存在するとき術後 成績が良好なものが多いとしている。

われわれの 7 例を大腿骨・脛骨の骨孔の位置により 分類すると表 5 のごとくである.

大腿骨側が至適領域にないものは，関節内勒帯内フ イラメントの断裂のみられた症例 1 のみである。すな わち症例 1 では, 脛骨側は $27.3 \%$ 至適領域内にある が, 大腿骨側は前後方向が $57.7 \%$, 上下方向が $48.8 \%$ と至適領域よりやや前下方に骨孔が存在していた。 伸展位での側面 X線（図 5 ) でみると, 勒帯は notch
部に接触しており，関節鏡で notch に相当する部分で 断裂がみられたこともあわせて，本例では人工靶帯が notch 部で impinge され摩耗破損されたものと考えら れる。したがって notch 部での impingeによる断裂を さけるためには, 福林ら を十分に行うとともに，脛骨骨孔の位置を村瀬らの至 適領域よりやや後方, すなわち 35～40\%の位㯰にもつ てくることが重要と考える。

人工勒帯を用いた再建術は, 将来的に有望な方法で はあるが，現時点では適応を放選し，より慎重な手術 手技にて行うべきであると考える。

$$
\text { ま と め }
$$

1. ダクロン人工䩲帯を用いて前十字靱帯再建術を 


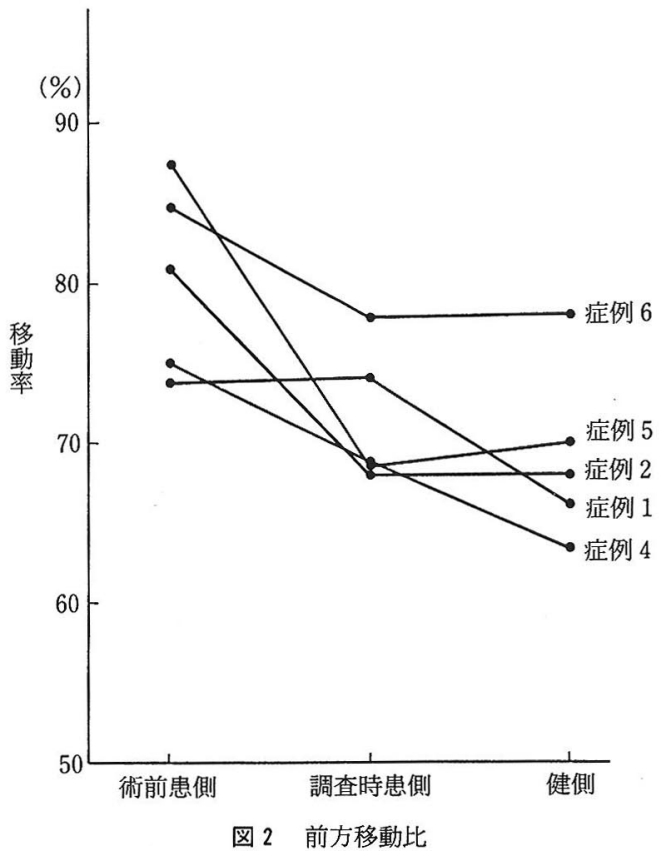

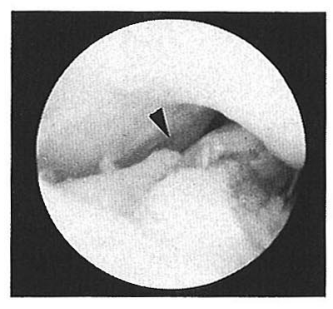

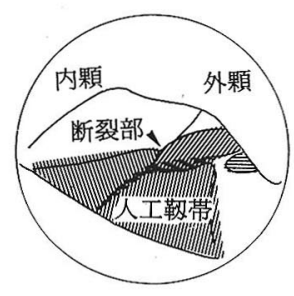

図 3 症例 1

術後 1 年の関節鏡所見：人工鞄帯は伸展位で notch に相当する部位で断裂を認める

行った 7 例の短期成績について報告した。

2. 自覚的には全例改善を認めるが，1例に関節内 靯帯の断裂を認め, また経時的に動摇性がやや増大傾 向を示す症例がみられた。

3. 鞋帯の断裂を認めた症例では, notch 部での摩耗 破損による断裂と考えられた。

4. notch 部での靯帯の impinge をさけるためには, notchplasty を充分に行い脛骨骨孔の位置を正常よりや や後方すなわち前方より 25～40\%の位置にもってくる ことが重要と考えられた。

$$
\text { 参 考 文 献 }
$$

1）福林 徹・他：スポーツ選手に対しての Gore-Tex人

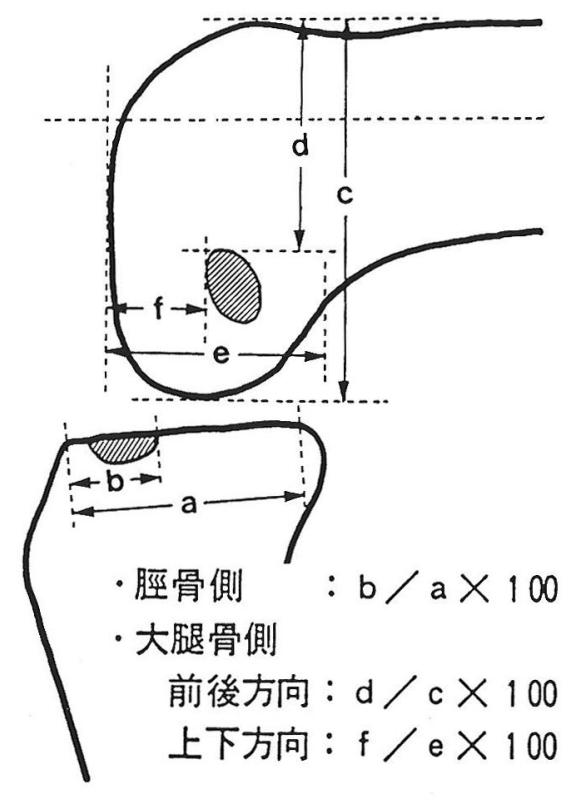

図 4 骨孔の位置の計測法

表 5 大腿骨側・脛骨側の骨孔の位置による分類 (村瀬ら)

\begin{tabular}{|c|c|c|c|c|}
\hline 脛骨側 & 至 適 & 領 域 & \multicolumn{2}{|c|}{ 至適領 域外 } \\
\hline $\begin{array}{l}\text { 至適領 域 } \\
\text { 至適領域外 }\end{array}$ & $\begin{array}{l}1 \\
5\end{array}$ & $\begin{array}{l}\text { 例 } \\
\text { 例 }\end{array}$ & $\begin{array}{l}1 \\
0\end{array}$ & $\begin{array}{l}\text { 例※ } \\
\text { 例 }\end{array}$ \\
\hline
\end{tabular}

※: 症例 1

工靱帯. 整形外科スポーツ医学会誌, $7: 11-14,1988$. 2）村瀬研一・他：前十字靶帯損傷䐂における再建靶帯の 走行と術後成績. $39: 1623-1629 ， 1988$.

質 問福岡大学 浅野 正也 術後ゆるみが出てくるというのは, 合併損傷や後療 法でもちがってくると思いますが,関節内再建のみと, 関節内外同時再建の両者共ゆるみが出てきたのでしょ うか。

\section{解 答熊本大学 佐久間克彦}

手術方法の違いでゆるむ傾向に違いはなかったＮ テスト陽性を示した症例 7 は両側 ACL 損傷膝であっ た. 


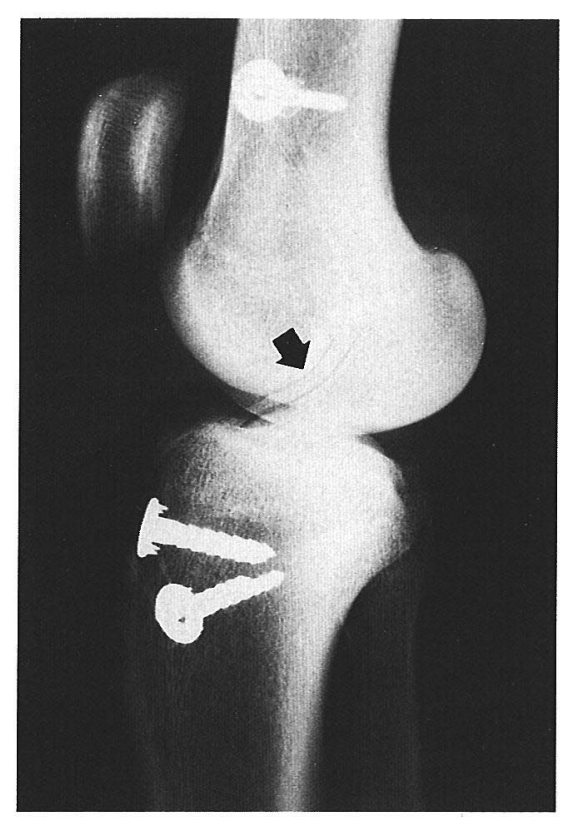

図 5 症例 1

側面 X線像 (伸展位)：人工靱帯は notch の屋根 の前方部分に impingeされている

\section{質 問 \\ 福岡大学 古賀 哲二}

(1) drilling は gillquist のジグを使用されていますか (日本人にあいますか).

(2) 正座可能例が 4 例, ですが, 正座の許可は術後
どの位よりされていますか。早期に正座を許可すると どうしても前方動摇性が出現するように思う。われわ れは 6 カ月間は正座および完全伸展を禁止している。

\section{解 答} 熊本大学 佐久間克彦

可動域は術後 2 週で free とし, 正座はその後必要性 が生じれば症例により許可した。ただし積極的には正 座を行わせていない。

\section{解 答 \\ 熊本大学 久保田健治}

今回, 症例を厳選し，時間的な制約などからどうし ても自家組織による再建術を施行することのできなか つた症例に限って本法を施行した。術後スポーツ活動 は行わないことが適応の原則である。そこで短期成績 を検討してみたが，長期成績には不安を残すものとな つた。人工勒带による再建術は将来的には有望なもの と思われるが，現時点では積極的には行っていこうと は思っていない。
追 加
長崎大学 乗松 敏晴
(1) 確かに人工勒帯は問題がありますが，この一年 間運動に全力をあげたいと希望をもつ，比較的レベル の場合どうするかの問題があります。

(2) 人工勒帯をいわゆる, 本来の augumentation と して使用すれば活路も？ 